\title{
CZY KONSTRUKCJE PYTAJĄCE W PODRĘCZNIKACH DO NAUCZANIA JEZZYKA POLSKIEGO JAKO OBCEGO REJESTRUJĄ NAJNOWSZY UZUS POLSZCZYZNY POTOCZNEJ?
}

\begin{abstract}
Słowa kluczowe: podręczniki do nauczania języka polskiego jako obcego, polszczyzna potoczna, uzus

Streszczenie. Artykuł jest próbą odpowiedzi na pytanie, czy konstrukcje pytające w podręcznikach do nauczania języka polskiego jako obcego rejestrują najnowszy uzus polszczyzny potocznej. W pracy zostały przedstawione wyniki ankiety, w której respondenci - studenci (w przedziale wiekowym od 20 do 39 lat) specjalizacji nauczanie języka polskiego jako obcego, mieli zdecydować czy struktury pytające umieszczone w podręcznikach do nauki polskiego, rzeczywiście są używane w codziennych rozmowach.
\end{abstract}

\section{WPROWADZENIE}

Z perspektywy teorii i praktyki nauczania języka polskiego jako obcego jednym z ważnych zagadnień jest frekwencja użycia zwrotów i form potocznych w podręcznikach do nauki polszczyzny. Temat niniejszego artykułu zrodził się w trakcie prowadzenia zajęć w Studium Języka Polskiego dla Cudzoziemców Uniwersytetu Łódzkiego. Jego słuchacze często podchodzili nieufnie do podręcznikowych tekstów i próbowali dowiedzieć się ode mnie jako lektora, czy Polacy rzeczywiście używają takich sformułowań, jak bohaterowie omawianych tekstów. Często obcokrajowcy wprost pytali: „tak Polacy mówią?” lub „czy tak się mówi?” Odpowiadałem wtedy, że Polacy używają także innych konstrukcji i wymieniłem, aby zaspokoić ich ciekawość, wersje bardziej potoczne. Zdarzało się, że studenci sami pytali, czy jakaś potoczna struktura, usłyszana podczas rozmów, jest po-

*rafalmac@o2.pl; Zakład Lingwistyki Stosowanej i Kulturowej, Instytut Filologii Polskiej i Logopedii, Wydział Filologiczny, 90-236 Łódź, ul. Pomorska 171/173. 
prawna. Z moich obserwacji wynika, że lektor nie może polegać w tym zakresie wyłączne na podręczniku. Niektóre teksty lub ich fragmenty brzmią bowiem sztucznie i nienaturalnie. Nie są też odzwierciedleniem obecnie panującego uzusu, a więc powszechnego zwyczaju używania, przez pewne środowiska, takich, a nie innych form językowych. Jak podaje Andrzej Markowski (1999), w skład uzusu wchodzą tylko te elementy językowe, które występują bardzo często w tekstach i wypowiedziach danej grupy społecznej.

W tytule artykułu pojawia się słowo potoczność, które nie jest łatwe do zdefiniowania. Ten problem dobrze obrazuje tytuł jednej z części artykułu Jerzego Bartmińskiego (2001) - spór o potoczność w języku i kulturze. Autor pisze, że istnieją dwie koncepcje potoczności - leksykalno-stylistyczna i antropologiczno-kulturowa. W pierwszym, węższym rozumieniu potoczność definiowana jest jako mniejsze zdyscyplinowanie gramatyczne, mniejsza staranność językowa oraz niski stopień normatywności (cecha definicyjna języka potocznego) (patrz Malinowska i in., red., 2013, s. 36). Natomiast w drugim, szerszym rozumieniu (antropologiczno-kulturowym) język potoczny postrzegany jest jako podstawa i centrum stylowe współczesnej polszczyzny (patrz tamże, s. 36-37). Przychylam się bardziej do drugiego stanowiska, które reprezentują tacy badacze jak: A. Furdal (1977), A. Wilkoń (1987) i J. Bartmiński (2001).

Styl potoczny / potoczność widoczne są głównie w rozmowie (Żydek-Bednarczuk 1994, s. 30), zarówno mówionej, jak i korespondencyjnej, czy też w zapisie rozmowy. Charakteryzuje się on między innymi dążeniem do skrótu bez dbałości o ścisłość sformułowań (Kurkowska, Skorupka 2001). Styl ten realizuje się (jak większość stylów) w określonym kontekście. Często wypowiedzi potoczne oderwane od kontekstu stają się niezrozumiałe. W artykule przedstawiam wyłącznie proste pytania, których Polacy często używają w (potocznych) rozmowach, a których jako lektorzy uczymy studentów języka polskiego jako obcego już na pierwszym etapie nauki.

W podjętych badaniach dość istotną okolicznością jest to, że do tej pory uczyłem wyłącznie grupy, którym zależało na poznaniu języka po to, by móc swobodnie komunikować się/rozmawiać ze znajomymi Polakami. Inne są potrzeby w przypadku takich grup, a jeszcze inne w grupach, które mają np. zdać egzamin certyfikatowy. Wtedy studenci są bardziej zainteresowani oficjalną odmianą języka i muszą dogłębniej zaznajomić się z systemem języka polskiego.

\section{OPIS REZULTATÓW BADAŃ WLASNYCH}

Aby zbadać, czy występujące w podręcznikach konstrukcje są nadal aktualne dla młodego pokolenia Polaków, stworzyłem ankietę. Jej celem było sprawdzenie, czy te podręcznikowe konstrukcje są nadal żywotne w codziennej mowie. 
Respondentami byli studenci specjalizacji nauczanie języka polskiego jako obcego. Ograniczyłem się wyłącznie do tej grupy, ponieważ te osoby będą w przyszłości lektorami i są już nieco zaznajomione z tematyką glottodydaktyczną. Z drugiej strony są też rodzimymi użytkownikami współczesnego języka polskiego i reprezentują młode pokolenie. Ankietę wypełniło 50 osób - absolwentów różnych kierunków filologicznych. Poniższe wykresy prezentują szczegółowe dane respondentów.

Wykres 1. Kierunek studiów respondentów

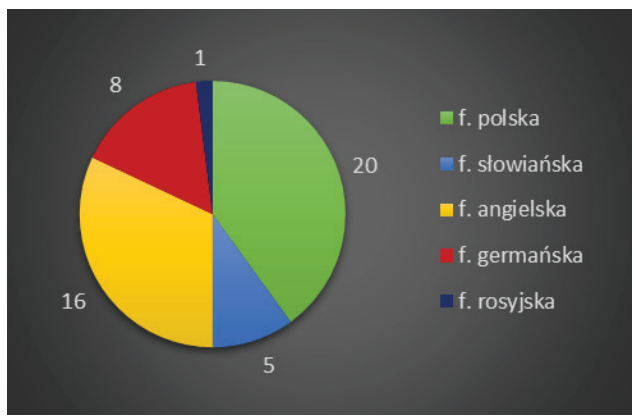

Źródło: opracowanie własne
Wykres 2. Płeć respondentów

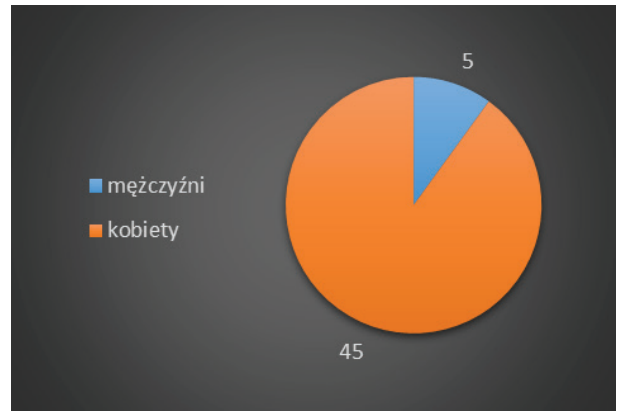

Źródło: opracowanie własne

Wykres 3. Wiek respondentów

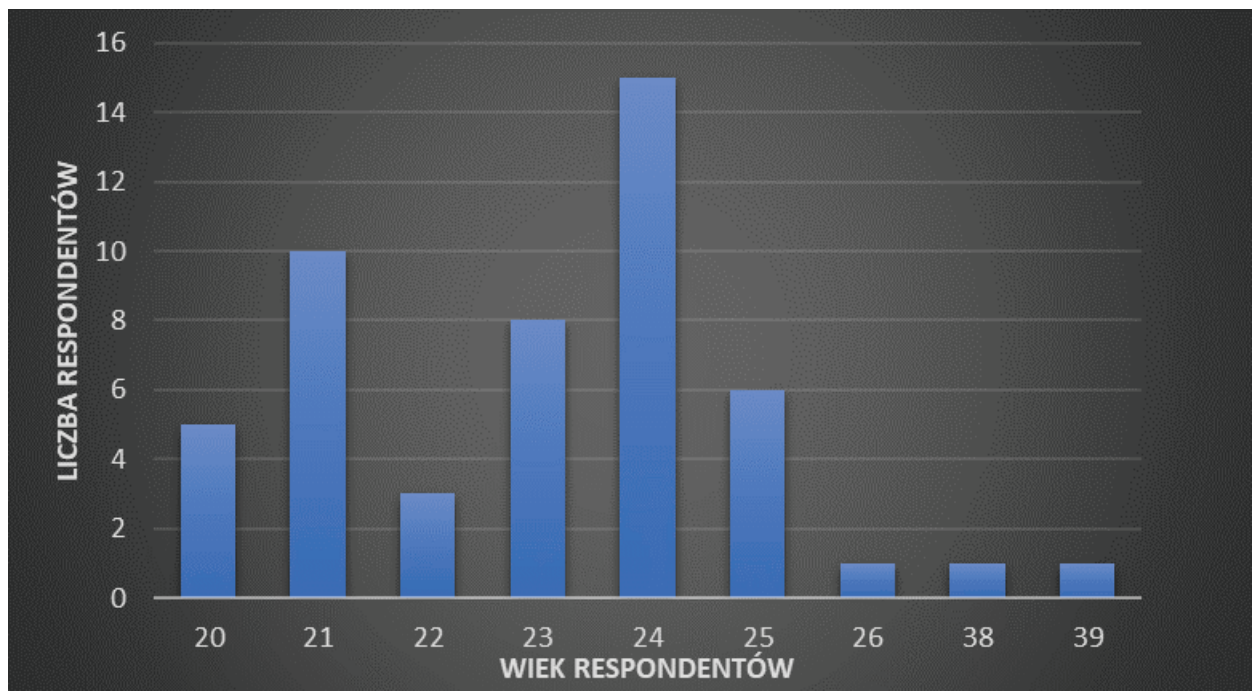

Źródło: opracowanie własne 
Konstrukcje umieszczone w ankiecie wybrane zostały z podręczników: Hurra!!! Po polsku 1, Polski, krok po kroku 1 i Polski jest cool ${ }^{1}$. Po wybraniu kilkudziesięciu struktur (pytań), poprosiłem ankietowanych, by ocenili, czy w codziennych rozmowach z kolegami, rodzicami lub profesorami używają danych konstrukcji (w takich formach, jakie zostały podane w podręcznikach). Wszystkie pytania, jeśli była taka możliwość, zostały zgrupowane w pola tematyczne, np. pytania o samopoczucie czy pytania o czas.

Najważniejszym elementem ankiety było pole „własne propozycje” (por. grafika 1.), w którym respondenci, po zapoznaniu się z kontekstem pytań w rubryce „z podręczników” mogli podać własne, bardziej aktualne wersje tych samych pytań.

Grafika 1. Prezentacja fragmentu ankiety ${ }^{2}$

\begin{tabular}{|l|l|}
\hline \multicolumn{1}{|c|}{ Z podręczników } & Wlasne propozycje \\
\hline 1. & \\
$\square \quad$ Jak się masz? & \\
$\square \quad$ Co nowego? & \\
$\square \quad$ Cześć, co u ciebie? & \\
$\square \quad$ Cześć. Co słychać? & \\
\hline
\end{tabular}

Źródło: opracowanie własne

Jeżeli respondenci używali w codziennych rozmowach pytania zaproponowanego w kolumnie ,z podręczników”, to zaznaczali kwadrat obok pytania, natomiast jeśli go nie używali, to zostawiali puste pole. Mogli przy tym zaznaczyć dowolną liczbę kwadratów (bo przecież w codziennych rozmowach można używać wszystkich zaproponowanych struktur), mogli także zostawić wszystkie kwadraty puste, jeśli nie używali żadnego z pytań. Jeśli zaznaczyli jakiś kwadrat/ jakieś kwadraty w rubryczce ,z podręczników”, to mogli także dopisać własne propozycje. Poniżej, w formie tabelki, prezentuję wyniki ankiety. W lewej kolumnie umieściłem pytania z podręczników wraz ze skrótową informacją o pochodzeniu tych pytań/źródle ${ }^{3}$. Natomiast w prawej kolumnie zaprezentowałem przy pomo-

${ }^{1}$ Wybrane do ankiety podręczniki przeznaczone są do nauki na poziomie A1. Poziom podręczników (A1) i popularność były kryterium wyboru tych pozycji do analizy.

${ }^{2} \mathrm{~W}$ ankiecie nie umieszczałem informacji z jakiego podręcznika pochodzą dane konstrukcje, żeby niczego nie sugerować respondentom. Informacje tę przedstawiam dopiero w tym artykule, przy prezentacji wyników.

${ }^{3} \mathrm{~W}$ nawiasach podaję źródło danej konstrukcji, stosując następujące skróty: C - Polski jest cool, H - Hurra!!! Po polsku 1, K - Polski, krok po kroku 1, a następnie podaję numer strony podręcznika, na której odnotowano użycie określonej struktury (bez określania frekwencji użycia w określonym źródle, gdyż dla moich badań nie jest to istotne). Większość pytań pochodzi z podręczników studenta, jednak jest także kilka z innych pomocy dydaktycznych np. z ćwiczeń. One 
cy wykresów słupkowych rozpowszechnienie proponowanych przez podręczniki pytań wśród wykształconych użytkowników języka. Pod tabelką umieściłem propozycje ankietowanych, z tym, że przyjąłem zasadę, iż w artykule prezentuję jedynie najpopularniejsze propozycje respondentów, czyli te, które przytoczone zostały przez minimum 2 osoby. Pojedyncze propozycje pominąłem.

Pierwsze dwa pytania dotyczyły godzin:

1) Która jest godzina? (C, s. 141, H, s. 64)

2) Która godzina? (H, s. 64 ${ }^{\text {a }}$ K, s. 80)

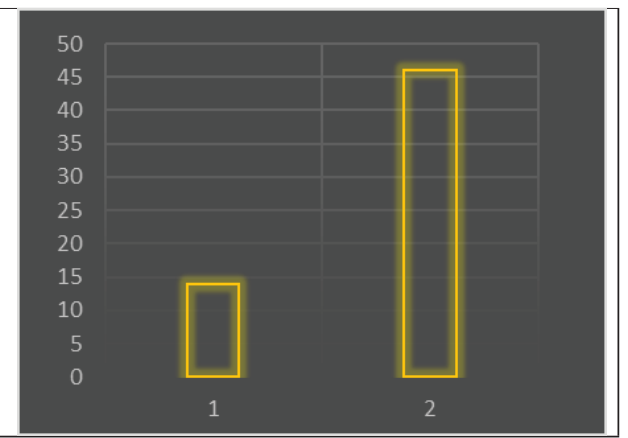

Najpopularniejsze propozycje ankietowanych (z 22)

$$
\begin{gathered}
\text { •Która jest? - } 11 \\
\text { •Jaki mamy czas? - } 3 \\
\text { •Masz zegarek? - } 2
\end{gathered}
$$

a Dosyć często zdarzało się, że poszczególne konstrukcje w różnych podręcznikach trochę się od siebie różniły np. podmiotem (Piotr zamiast Katarzyna) czy też stylem (formalny zamiast nieformalnego). Starałem się wtedy ujednolicić przykłady pozostawiając jedną konstrukcję. Były to drobne zmiany, np. zamiana dokąd jedziesz na dokąd idziesz w pytaniu badającym użycie zaimka dokąd. Wersje oryginalne z podręczników podaję w przypisach.

W tym przypadku podręcznik podaje konstrukcję która (jest) godzina?, z opcjonalnym czasownikiem być. W ankiecie umieściłem dwie możliwe wersje pytania i oznaczyłem, że obie występują w podręczniku Krok po kroku.

Podręczniki uczą dwóch wersji pytania o godzinę - z czasownikiem być i z jego pominięciem. Ankietowani w mowie codziennej zdecydowanie częściej używają krótszego wariantu. Wśród propozycji własnych dominuje wersja pytania z pominięciem rzeczownika godzina, która możliwa jest do użycia tylko w określonej sytuacji komunikacyjnej, poza nią może dotyczyć nie tylko pytania o godzinę, ale także np. o miejsce w kolejce (Kasia stoi w kolejce? Która jest?).

także zostały oznaczone skrótami: C[Zć] - Polski jest cool. Zeszyt ćwiczeń, H[Pn] - Hurra!!! Po polsku 1. Podręcznik nauczyciela, K[Zć] - Polski, krok po kroku 1. Zeszyt ćwiczeń. Wykorzystałem także dwa pytania z podręcznika Polski, krok po kroku 2 (K[2]) w celu uzupełnienia, ponieważ analogiczna konstrukcja w pozostałych dwóch podręcznikach wprowadzana jest na poziomach A1. 


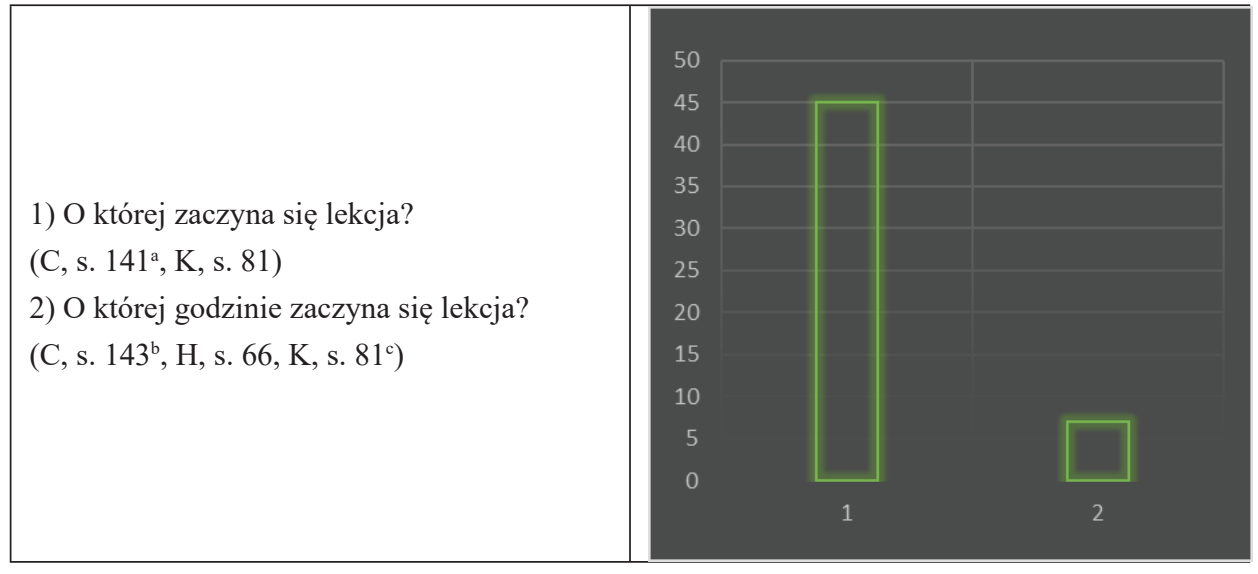

\section{Najpopularniejsze propozycje ankietowanych (z 16)}

-Kiedy zaczyna się lekcja? - 5

-O której zaczynamy? - 4

-O której jest lekcja? - 3

-Kiedy mamy zajęcia? - 2

a Podręcznik podaje: o której jest lekcja polskiego?

b Podręcznik podaje: o której godzinie...? (konstrukcja, którą trzeba uzupełnić).

c Podręcznik podaje: o której (godzinie)...? (konstrukcja z opcjonalnym rzeczownikiem i miejscem do uzupełnienia).

W podręcznikach po zapoznaniu studentów z pytaniem o godzinę, następuje pytanie o której coś się zaczyna. Tutaj także ankietowani preferują krótszą wersję, z pominięciem rzeczownika godzina. Natomiast wśród propozycji najwięcej pytanych proponuje zmodyfikowanie tego pytania, czyli wykorzystanie zaimka pytającego kiedy.

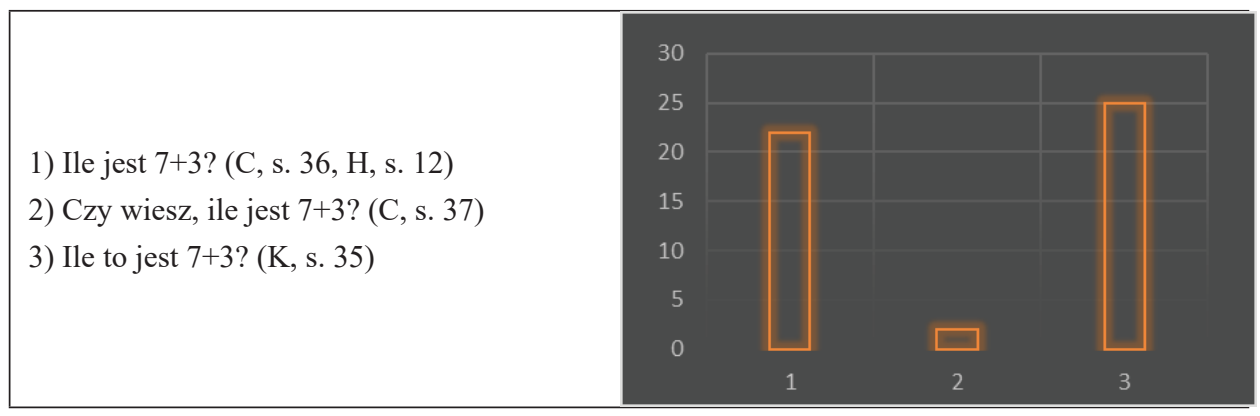

Najpopularniejsze propozycje ankietowanych (z 14)

-Ile to $7+3 ?-3$

$\bullet 7+3$ to $\ldots ?-3$ 
W przypadku tego pytania respondenci niemal po równo zaznaczyli, że używają 1. i 3. konstrukcji. Natomiast konstrukcja z czy wiesz prawie nie jest przez nich używana. W propozycjach dominują krótkie pytania: z pominięciem czasownika być oraz z prośbą o dokończenie przez drugą osobę wypowiedzi (oznaczone wielokropkiem).

1) Jaki masz adres mailowy? (K, s. 30)

2) Jaki masz e-mail? (C, s. 28)

3) Jaki masz adres e-mailowy? (H, s. 33a)

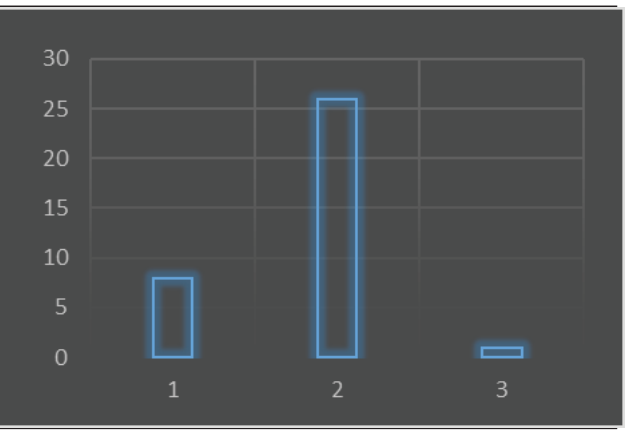

Najpopularniejsze propozycje ankietowanych (z 49)

$$
\begin{gathered}
\text { •Jakiego masz maila? - } 7 \\
\text { •Jaki jest twój e-mail }-7 \\
\text { •Jaki masz mail } \text { - } 4 \\
\text { •Podaj maila. }-3 \\
\text { •Podasz swój e-mail? - } 2
\end{gathered}
$$

a Podręcznik podaje: Jaki Pan/Pani ma adres e-mailowy?

W odróżnieniu od poprzednich grup pytań, w których dodany lub odjęty był pewien element pytania, tutaj mamy trzy różne wersje odnoszące się do tego samego obiektu (e-mail). W podręcznikach znacząco dominuje wersja najkrótsza. Natomiast w propozycjach aż 7 osób wskazało nieakceptowalną przez językoznawców konstrukcję z formą dopełniaczową - maila. Jednak w mowie Polaków słyszy się ją bardzo często.

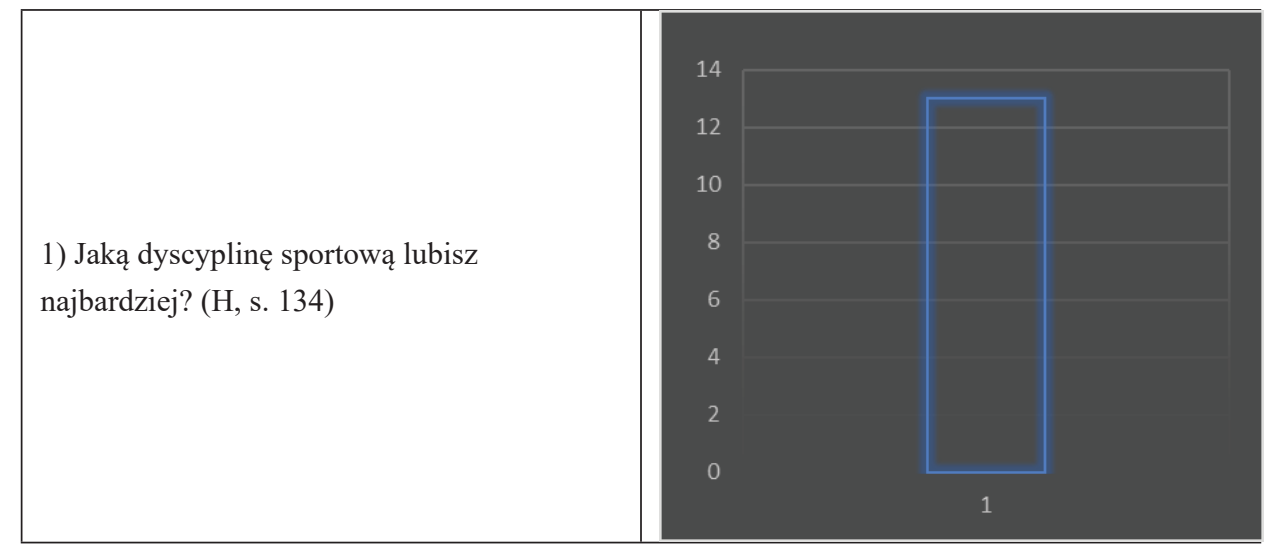




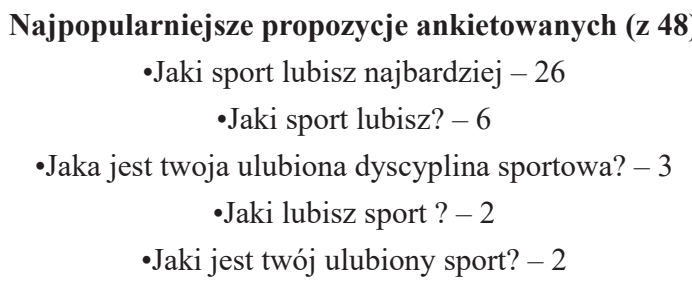

Tylko 13 z 50 respondentów w rozmowach codziennych używa pytania z określeniem dyscyplina sportowa. Większość, bo aż 26 ankietowanych zamienia tę konstrukcję dwuelementową (rzeczownik + przymiotnik) na jednoelementową, czyli na rzeczownik - sport.

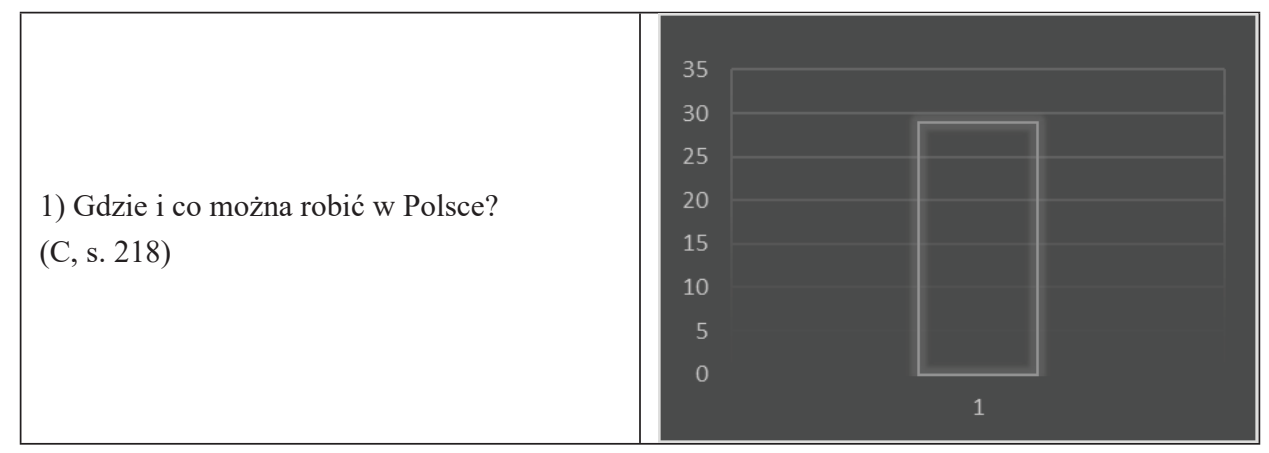

\footnotetext{
Najpopularniejsze propozycje ankietowanych (z 16)

-Co można robić w Polsce? - 4

-Co można zobaczyć w Polsce? - 3

-Co ciekawego można robić w Polsce? - 2
}

Pytanie to różni się od poprzednich tym, że zawiera w sobie dwa zaimki pytające. Ponad połowa ankietowanych (29) używa go w komunikacji. Wśród propozycji najwięcej osób wskazało, że zamiast pytania podręcznikowego używa - co można robić w Polsce? Jest to pytanie o jedną informację (co można robić?), brakuje natomiast pytania o to gdzie to coś można robić. Można założyć, że ankietowani dopytaliby o to w kolejnym pytaniu. 


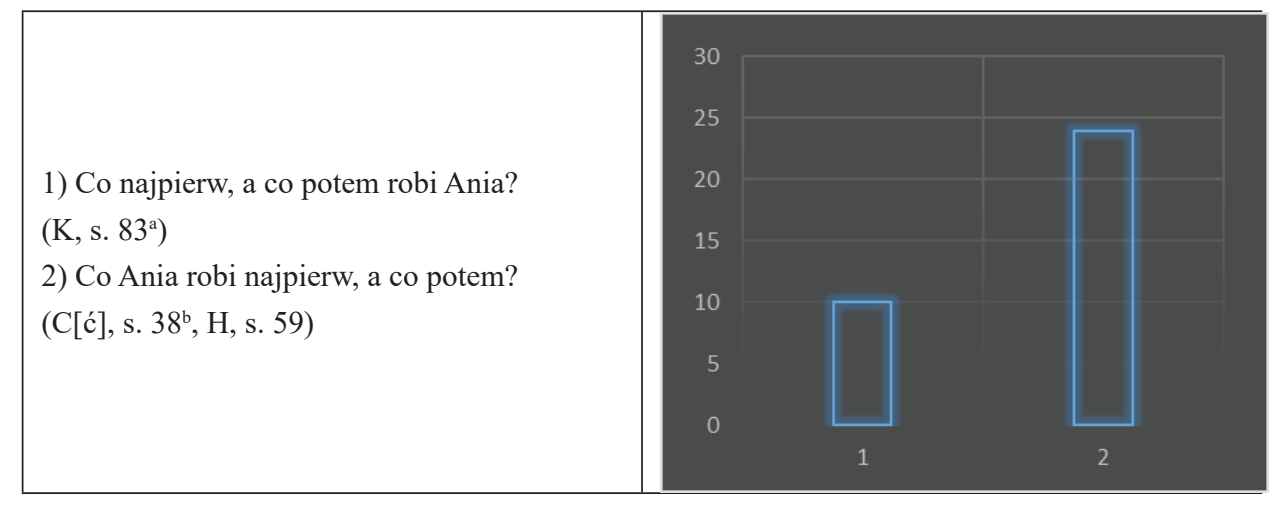

Wśród 9 proponowanych przez ankietowanych propozycji, żadna nie powtórzyla się.

a Podręcznik podaje: Co najpierw, a co potem robi Ania?

${ }^{b}$ Podręcznik podaje: Co robisz najpierw, a co potem?

Tutaj także mamy podwójne pytanie. Wersje pytań umieszczonych w tej grupie, różnią się między sobą miejscem występowania podmiotu (Ania) oraz orzeczenia (robić). Bliższe ankietowanym jest pytanie z podmiotem na drugim miejscu i orzeczeniem występującym zaraz po nim. Wśród 9 propozycji własnych, wszystkie były niepowtarzalne i jednostkowe, jednak można w nich wskazać pewne elementy wspólne: 4 ankietowanych w pytaniach zamieniło wyraz potem na później (np. co Ania robi najpierw, a co później?), 2 ankietowanych zastąpiło najpierw na teraz (np. co Ania robi teraz, a co potem?), zaś jedna osoba zapytała - jakie Ania ma plany?

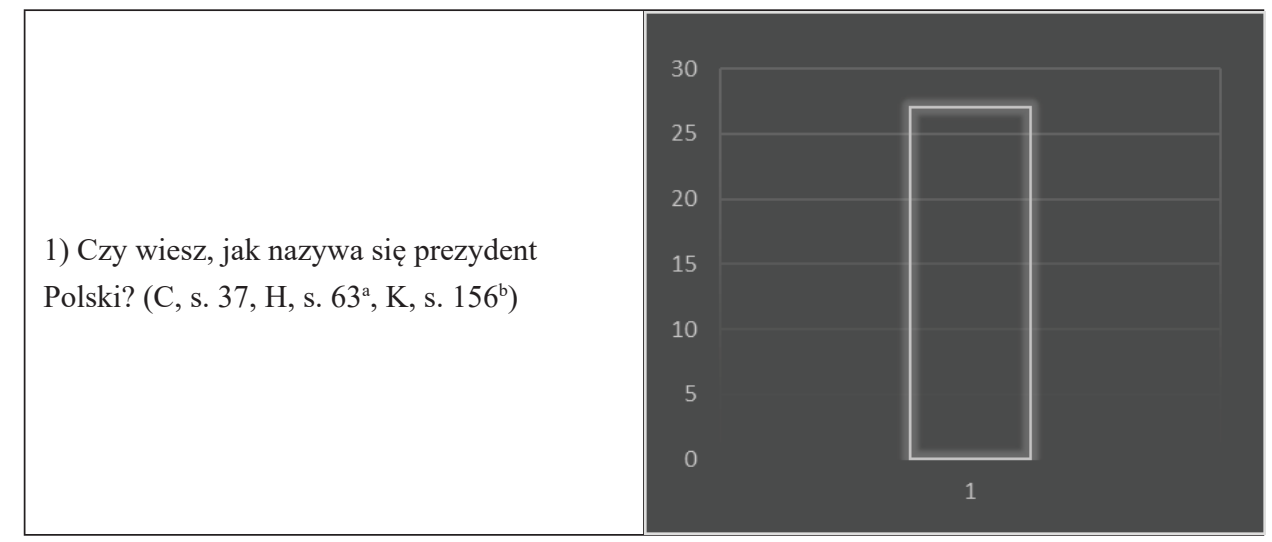




\section{Najpopularniejsze propozycje ankietowanych (z 25)}

-Kto jest prezydentem Polski? - 8

-Czy wiesz, kto jest prezydentem Polski? - 6

-Jak nazywa się prezydent Polski? - 5

-Jak się nazywa prezydent Polski? - 2

a Podręcznik podaje: Czy wiesz, jak nazywa się polski prezydent?

${ }^{\text {b }}$ Podręcznik podaje: Czy wiesz, jak nazywa się stolica Polski?

Tej bardziej rozbudowanej o element $c z y$ wiesz, konstrukcji podręcznikowej używa nieco ponad połowa ankietowanych (27 osób), natomiast najpopularniejsza propozycja własna respondentów to konstrukcja narzędnikowa z użyciem zaimka kto. Jest to krótsza wersja od tej przedstawionej w podręczniku, a znaczy dokładnie to samo.

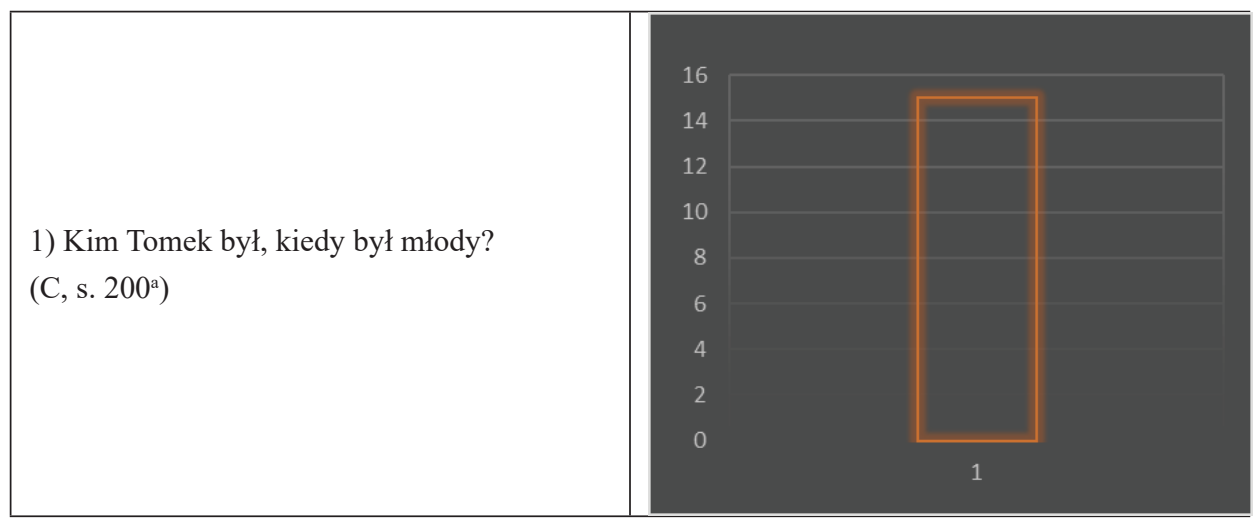

Najpopularniejsze propozycje ankietowanych (z 30)

-Kim był Tomek w młodości? - 6

-Kim był Tomek, kiedy był młody? - 6

-Kim był Tomek, jak był młody? - 4

-Co robił Tomek, kiedy był młody? - 2

a Podręcznik podaje: Kim on byt, kiedy byt młody?

Kolejne z bardziej rozbudowanych pytań. Wersji, której nauczamy obcokrajowców używa raptem 15 osób. Ankietowani zaproponowali, by zastąpić strukturę kiedy byt młody krótszą konstrukcją miejscownikową $w$ młodości, natomiast w drugiej, równie popularnej propozycji, respondenci zamienili szyk, czyli czasownik być umieszczony został nie na trzeciej, a na drugiej pozycji zaraz po zaimku pytającym kim. 


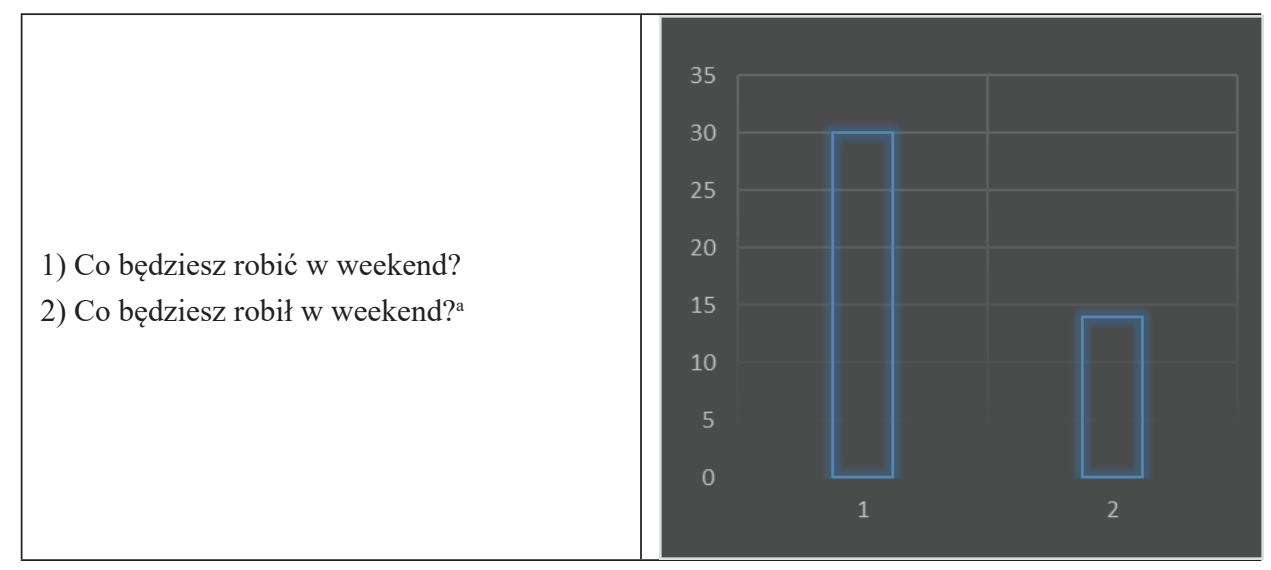

Najpopularniejsze propozycje ankietowanych (z 32)

-Co robisz w weekend? -23

-Masz plany na weekend? - 2

${ }^{a}$ Wszystkie podręczniki wprowadzają oba warianty tworzenia czasu przyszłego.

Podczas lektoratu wprowadza się dwa sposoby tworzenia czasu przyszłego $\mathrm{z}$ wykorzystaniem czasowników $\mathrm{w}$ aspekcie niedokonanym. Pierwszy oparty jest na bezokoliczniku, a drugi na 3 osobie czasu przeszłego. Postanowiłem sprawdzić, który sposób jest częściej wykorzystywany przez ankietowanych. Przeważającą liczbą głosów zwyciężył wariant prostszy, wykorzystujący bezokolicznik. Natomiast respondenci zaproponowali jeszcze trzecią wersję pytania o weekendowe plany, a mianowicie kontekstowe pytanie, wykorzystujące formę czasu teraźniejszego (co robisz w weekend?). Konstrukcji tej używa aż 23 ankietowanych.

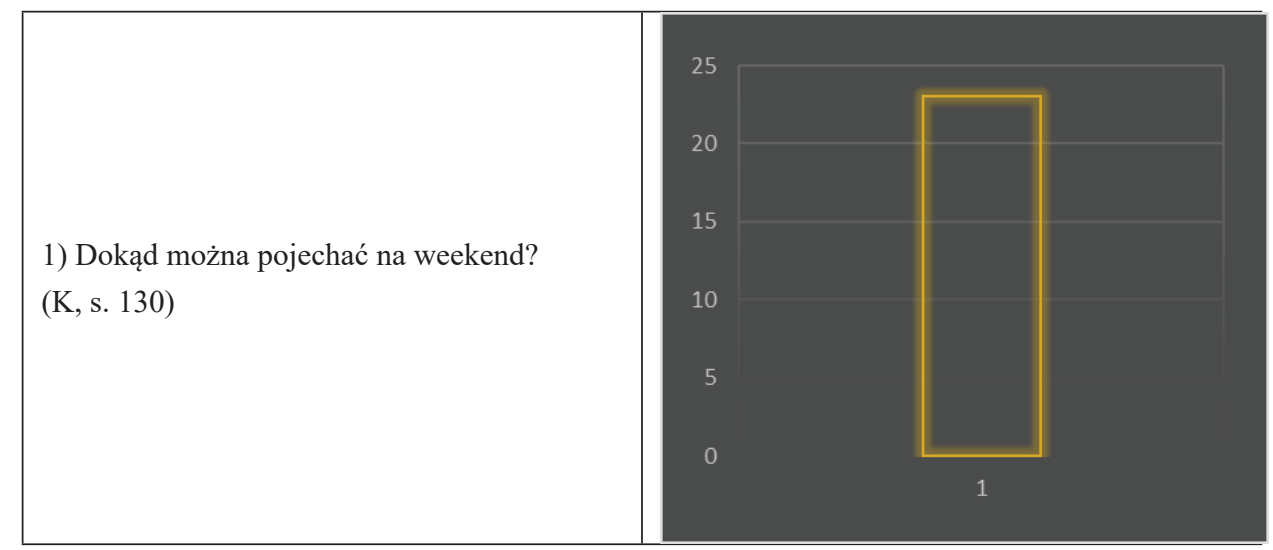




\section{Najpopularniejsze propozycje ankietowanych (z 37)}

-Gdzie można pojechać na weekend? - 14

-Gdzie można jechać na weekend? - 5

-Gdzie można pojechać w weekend? - 2

-Gdzie możemy pojechać na weekend? - 2

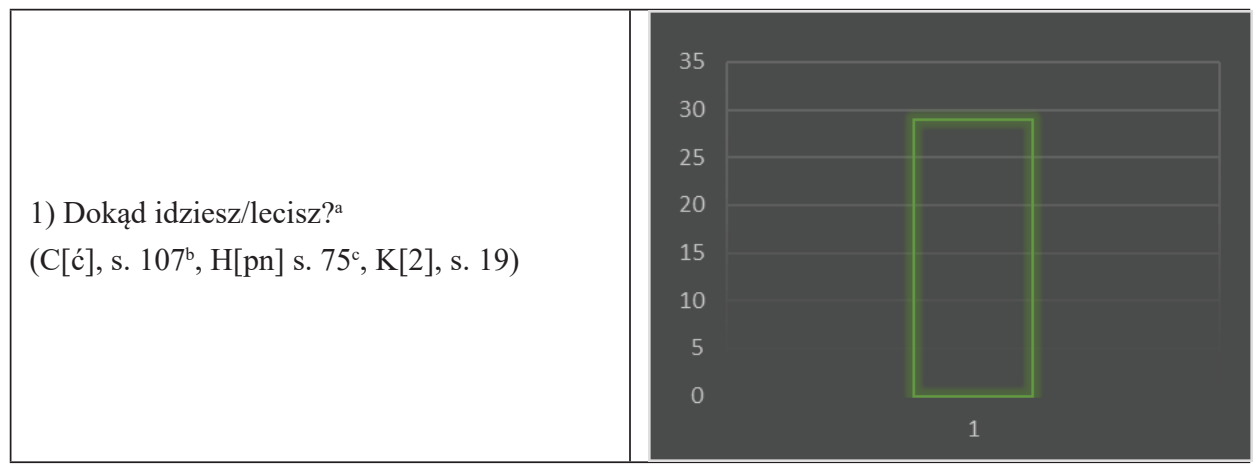

Najpopularniejsze propozycje ankietowanych (z 43)

•Gdzie idziesz? - 27

-Gdzie lecisz? - 6

-Gdzie idziesz/ lecisz? - 3

-Gdzie pędzisz? - 2

a Przed rozdaniem respondentom ankiet, zaznaczałem, że czasownik lecieć występuje tu w znaczeniu 'przebywać jakaś przestrzeń w powietrzu' (www.sjp.pwn.pl/sjp/leciec;2477691.html), a nie 'spieszyć się, biec'.

${ }^{\mathrm{b}}$ Podręcznik podaje: Dokąd jedziesz?

${ }^{c}$ Przykład pochodzi z gry planszowej o przyimkach, którą wprowadzamy na lekcji języka polskiego.

W dwóch powyżej przedstawionych pytaniach, wykorzystano zaimek pytający - dokad. W obu przypadkach ankietowani zamieniliby ten zaimek na inny - gdzie. W drugim pytaniu wśród wszystkich propozycji (43) tylko dwie wykorzystywały zaimek dokad, natomiast w pierwszym z 37 propozycji było 30 z gdzie, 2 z dokad i 5 zupełnie innych konstrukcji (np. co można robić $w$ weekend? czy jakie miejsca polecasz na weekend?). 


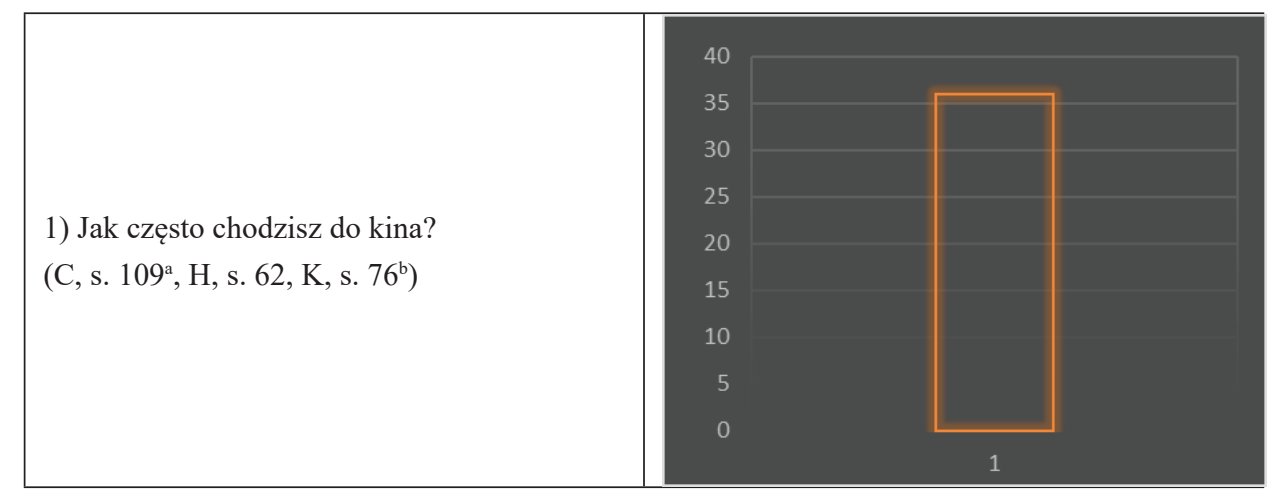

Najpopularniejsze propozycje ankietowanych (z 16)

-Często chodzisz do kina? - 11

-Jak często bywasz w kinie? - 2

-Czy często chodzisz do kina? - 2

a Podręcznik podaje: Jak często Pani/ Pan pije alkohol?

b Podręcznik podaje: Jak często pracujesz?

Aż 36 respondentów używa pytania w identycznej formie, jakiej nauczają podręczniki. Natomiast 11 osób pomija w tym pytaniu człon jak.

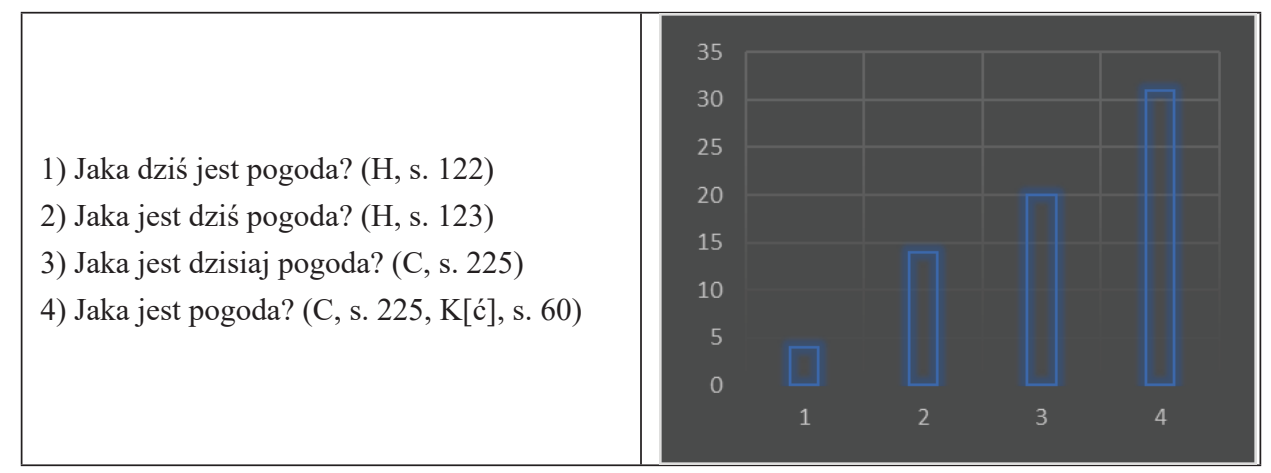

Najpopularniejsze propozycje ankietowanych (z 24)

-Jaka pogoda? - 4

-Jaka dziś pogoda? - 2

-Jak jest dzisiaj? - 2

$$
\text { -Pada? - } 2
$$

-Jak jest na zewnątrz? - 2 
Trzy z czterech pytań w tej grupie zawierały wyraz dzisiaj lub jego krótszy wariant $d z i s ́$, natomiast jedno z pytań w grupie było uboższe o ten wyraz i okazało się, że najwięcej ankietowanych wybrało właśnie ten najkrótszy wariant, zaś 4 osoby zaproponowały jeszcze krótszy wariant tego pytania, bo dwuelementowy - Jaka pogoda? Natomiast 2 ankietowanych zaproponowało pytanie jednoelementowe - Pada? Należy założyć, że w ich przypadku pytanie o pogodę oznacza pytanie o deszcz, śnieg lub grad i konieczność zebrania ze sobą parasola.

Trzy grupy pytań zaprezentowane poniżej miały na celu sprawdzenie, jaki szyk jest częściej przez ankietowanych używany w rozmowach.

1) Co robił pan w zeszłym tygodniu?

(H, s. $87, \mathrm{~K}$, s. $\left.91^{\mathrm{a}}\right)$

2) Co pan robił w zeszłym tygodniu?

(C, s. 213)

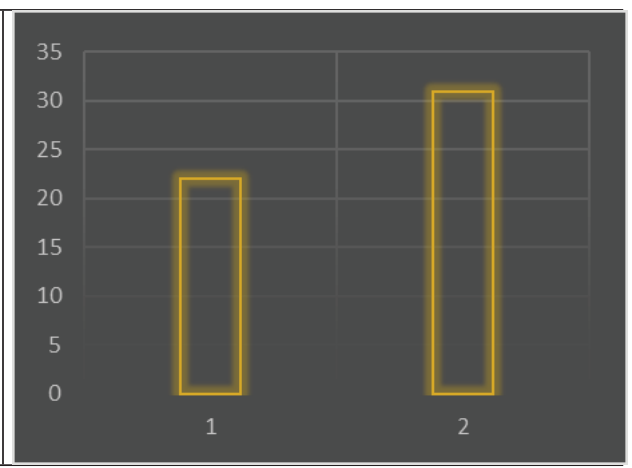

Wśród 5 proponowanych przez ankietowanych propozycji, żadna nie powtórzyła się.

${ }^{\text {a }}$ Podręcznik podaje: Co on robit w zeszłym tygodniu?

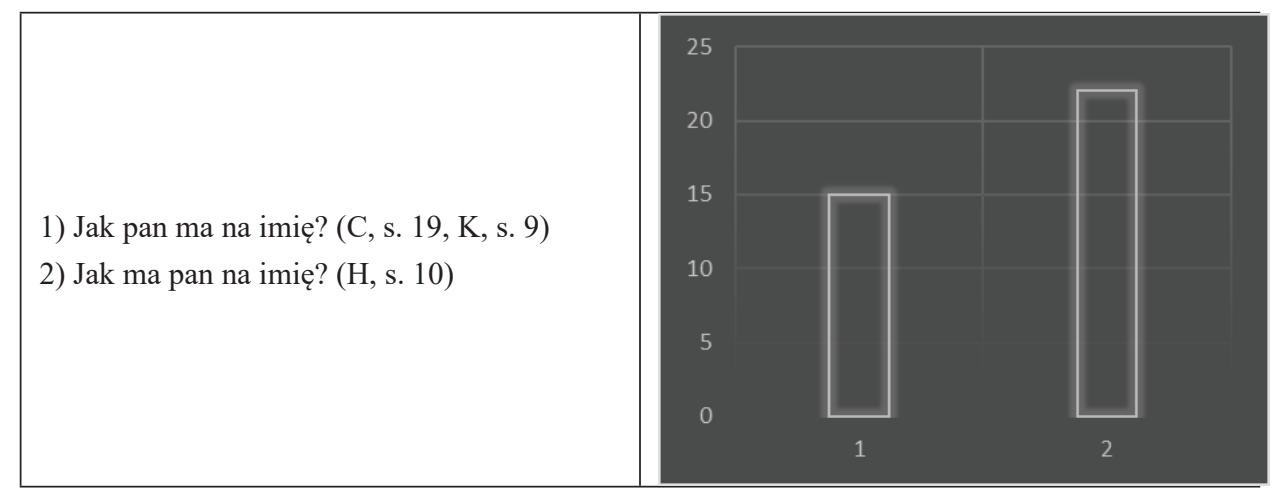

Najpopularniejsze propozycje ankietowanych (z 17)

•Jak się Pan nazywa? - 10 


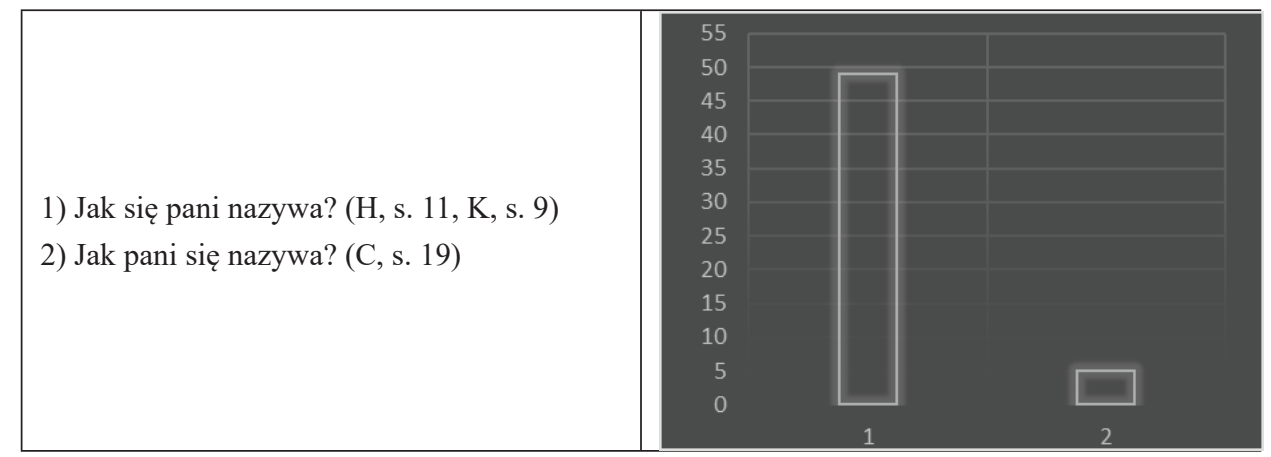

Wśród 2 proponowanych przez ankietowanych propozycji, żadna nie powtórzyła się.

W pierwszej grupie pytań ankietowani zdecydowali, że najbliższy jest im szyk z czasownikiem na trzeciej pozycji. W drugim zestawieniu więcej głosów oddano na konstrukcję z czasownikiem na drugiej pozycji, zaś w trzeciej grupie przeważającą liczbą głosów zwyciężyła konstrukcja z zaimkiem się na drugiej pozycji. W przypadku drugiej grupy zaobserwować można, że ankietowani, jako zamiennik pytania o imię podali jak się pan nazywa - jest to błędny odpowiednik.

1) Jaki numer telefonu ma Pani? (H, s. 12 $)$

2) Jaki Pani ma numer telefonu? (H, s. 53)

3) Jaki ma pani numer telefonu? (C, s. 24)

4) Jaki jest pani numer telefonu? (K[2], s. 9)

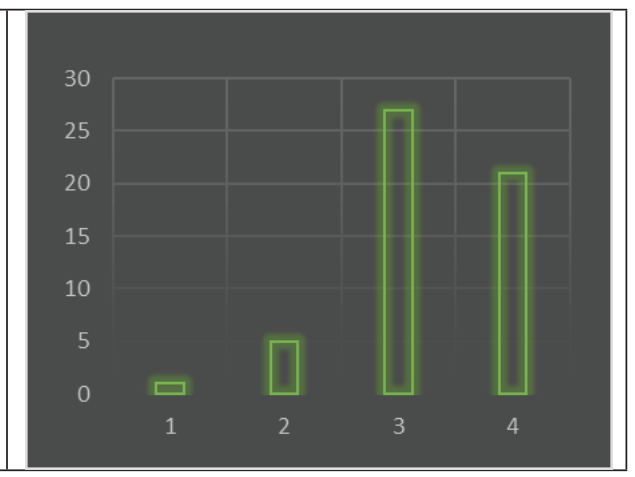

\section{Najpopularniejsze propozycje ankietowanych (z 12)}

-Mogę prosić o pani numer telefonu? - 3

-Jaki jest pani numer? - 2

a Podręcznik podaje: Jaki numer telefonu ma Pani...? (konstrukcja, którą trzeba uzupełnić).

Powyższa grupa pytań także w dużej mierze dotyczyła szyku konstrukcji językowych. Trzy pytania zbudowane zostały z wykorzystaniem czasownika mieć, a jedno z być. Najwięcej głosów ankietowani oddali na wariant z czasownikiem mieć na drugiej pozycji. Dużo głosów uzyskało także pytanie z czasownikiem być. 
Zestawiając wszystkie grupy z pytaniami, w których zamieniony został wyłącznie szyk, zaobserwować można, że w większości przypadków ankietowani wolą, gdy czasownik występuje bliżej początku danego pytania (oczywiście jeśli w pytaniu występuje taka możliwość). Jednak jest to zbyt mały materiał, by móc jednoznacznie postawić tezę na temat preferowanego przez współczesnych, rodzimych użytkowników języka polskiego szyku pytań.

1) Masz ochotę pójść do kina? (K, s. 78)

2) Chcesz pójść do kina? (K, s. 78)

3) Może pójdziemy do kina? (H, s. $69^{\mathrm{a}}$, K, s. 78)

4) Idziemy do kina? (C, s. $\left.183^{\text {b }}\right)$

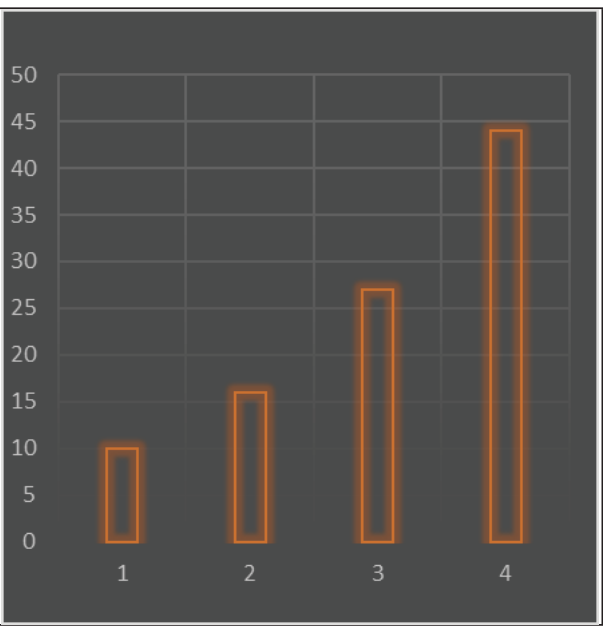

Najpopularniejsze propozycje ankietowanych (z 37)

-Chcesz iść do kina? - 13

-Chodźmy do kina. -6

-Pójdziemy do kina? - 5

-Masz ochotę na kino? - 3

-Może kino? - 2

-Chodź do kina. -2

${ }^{\text {a }}$ Podręcznik podaje: Może pójdziemy do teatru?

b Podręcznik podaje: Idziemy na pizzę? W ćwiczeniu występuje także wariant z do kawiarni (konstrukcja z dopełniaczem).

Zaprezentowano tutaj grupę, w której umieszczone zostały pytania, ale także propozycje wyrażone imperatywem (chodźmy do kina, chodź do kina), których używamy, gdy chcemy komuś coś zaproponować, np. wspólne wyjście do kina. Największą liczbę głosów uzyskało najkrótsze z zaproponowanych pytań.

Na zakończenie przedstawiam zestawienie pytań, które wyróżniają się na tle pozostałych liczbą własnych propozycji respondentów: 


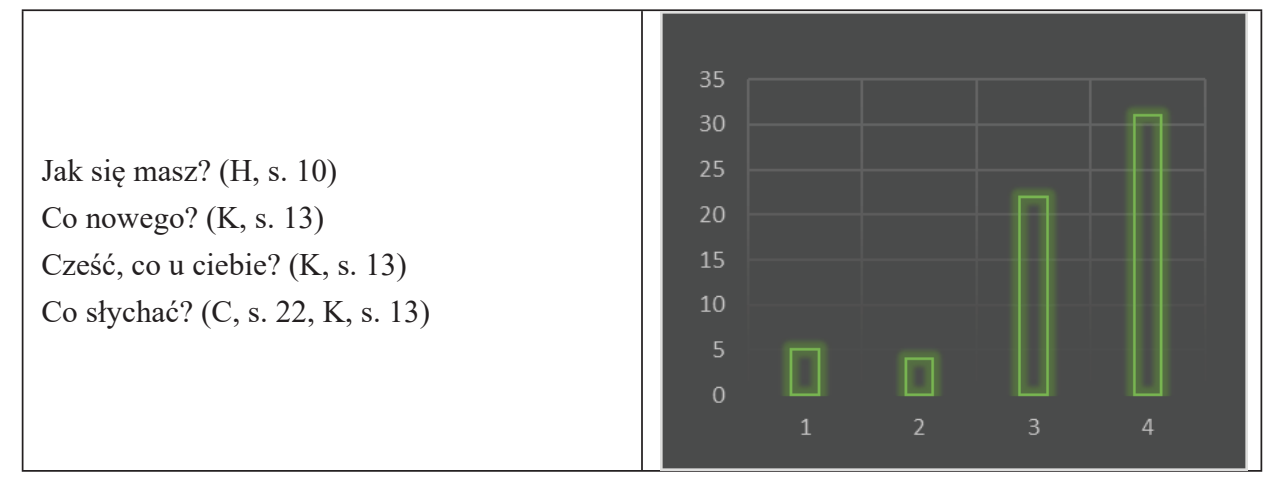

Najpopularniejsze propozycje ankietowanych (z 78)

$$
\begin{gathered}
\text { •Co tam? - } 27 \\
\text { •Jak tam? - } 14 \\
\text { •Cześć. Co tam? - 4 } \\
\text { •Jak leci - 4 } \\
\text { •Hej. Co tam? - 3 } \\
\text { •Hej, co tam? - 3 }
\end{gathered}
$$

Wziąwszy pod uwagę wszystkie wersje pytań, zarówno te podręcznikowe, jak i własne propozycje ankietowanych, to najwięcej głosów (32) uzyskało pytanie podręcznikowe co stychać? Co ciekawe, na drugim miejscu uplasowało się krótkie pytanie wyłonione z propozycji respondentów - co tam? Może więc warto umieścić je w podręczniku do nauki języka polskiego jako obcego, choćby w jakimś wybranym młodzieżowym tekście źródłowym.

\section{PODSUMOWANIE WYNIKÓW BADAŃ}

W tym miejscu, na podstawie przeprowadzonych badań, należy odpowiedzieć na pytanie - w którym z badanych podręczników umieszczone zostały najbardziej aktualne, wykorzystywane w codziennych rozmowach konstrukcje? Aby odpowiedzieć na to pytanie, wykorzystam poniższy wzór do analizy statystycznej:

$$
\frac{y}{z * 50}=x
$$

$y$ - suma zaznaczeń przez ankietowanych wszystkich pytań z danego podręcznika

$z$ - liczba wszystkich wykorzystanych w ankiecie pytań z danego podręcznika

50 - maksymalna liczba zaznaczeń użycia jednego pytania w ankiecie (liczba ankietowanych)

$x$ - średnia liczba używanych przez ankietowanych pytań z danego podręcznika 
Przykładowo z podręcznika Polski jest Cool $1 \mathrm{w}$ ankiecie wykorzystałem łącznie 22 pytania (z). Ankietowani (50) mogli zaznaczyć, że w codziennej komunikacji wykorzystują wszystkie zaproponowane $\mathrm{w}$ ankiecie pytania $\mathrm{z}$ tego podręcznika, czyli łącznie zaznaczeń mogło być $1100(z * 50)$, ale w rzeczywistości było ich $524(y)$. Po wykonaniu dzielenia $\frac{524}{1100}$, okazało się, że średnio jeden respondent wykorzystuje w rozmowach $47,6 \%(0,476)$ konstrukcji pytających użytych w ankiecie i pochodzących z tego podręcznika. Po przeprowadzeniu analogicznych wyliczeń okazało się, że identyczny wynik otrzymał podręcznik Polski, krok po kroku 1. Natomiast średnio jeden respondent używa 39,2\% pytań z podręcznika Hurra!!! Po polsku 1. Żaden podręcznik nie przekroczył progu 50\%. Pojawia się więc pytanie czy uczymy rzeczywistych, autentycznych konstrukcji pytających, przydatnych w komunikacji z Polkami?

Reasumując, w najważniejszej części przeprowadzonej ankiety, czyli w kolumnie „własne propozycje”, ankietowani wpisali aż 532 propozycje. Były to używane w codziennych rozmowach pytania. Respondenci proponowali zdecydowanie krótsze wersje pytań, niż te przedstawione w podręcznikach i bardziej kontekstowe oraz np. z innymi zaimkami (gdzie zamiast dokad). Zdarzały się także propozycje niepoprawne, ale w potocznych rozmowach akceptowalne, bo niestety większa jest szansa na to, że obcokrajowiec zetknie się z formą jakiego masz maila? niż jaki masz mail? Czy więc istnieje potrzeba zwiększania udziału form potocznych w podręcznikach do nauczania języka polskiego jako obcego? Biorąc pod uwagę wyłącznie wyniki ankiety, należałoby odpowiedzieć twierdząco. Warto jednak pamiętać, że poza podręcznikiem dużą rolę w nauczaniu języka polskiego jako obcego odgrywa nauczyciel, który także może wzbogacić kurs językowy o pewne elementy potoczne.

\section{BIBLIOGRAFIA}

Bartmiński J., Styl potoczny, w: J. Bartmiński (red.), Wspótczesny język polski, Lublin 2001, s. $115-134$.

Dawidek S., Stelmach A., Stempek I., Szymkiewicz A., Polski, krok po kroku 1, Kraków 2010.

Furdal A., Językoznawstwo otwarte, Opole 1977.

Kurkowska H., Skorupka S., Stylistyka polska. Zarys, Warszawa 2001.

Malinowska E., Nocoń J., Żydek-Bednarczuk U. (red.), Style współczesnej polszczyzny. Przewodnik po stylistyce polskiej, Kraków 2013.

Małolepsza M., Szymkiewicz A., Hurra!!! Po polsku 1, Kraków 2006.

Małolepsza M., Szymkiewicz A., Hurra!!! Po polsku 1. Podręcznik nauczyciela, Kraków 2008.

Markowski A. (red.), Nowy słownik poprawnej polszczyzny, Warszawa 1999.

Piotrowska-Rola E., Porębska M., Polski jest cool. Książka studenta, Lublin 2012. 
Piotrowska-Rola E., Porębska M., Polski jest cool. Zeszyt ćwiczeń, Lublin 2012. Stempek I., Grudzień M., Polski, krok po kroku. Zeszyt ćwiczeń 1, Kraków 2010. Stempek I., Stelmach A., Polski, krok po kroku 2, Kraków 2010.

Wilkoń A., Typologia odmian językowych wspótczesnej polszczyzny, Katowice 1987. Żydek-Bednarczuk U., Struktura tekstu rozmowy potocznej, Katowice 1994. www.sjp.pwn.pl/sjp/leciec;2477691.html [5.09.2016].

\section{Rafat Maćkowiak}

\section{IS THE CONTEMPORARY COLLOQUIAL POLISH WELL REFLECTED IN THE USE OF QUESTIONS IN POLISH AS A FOREIGN LANGUAGE TEXTBOOKS?}

Keywords: Polish as a foreign language textbooks, colloquial Polish

Summary. The article discusses the issue whether the contemporary colloquial Polish is well reflected in the use of questions in Polish as a foreign language textbooks. It presents the results of a survey in which the respondents (from 20 to 39 years old) - prospective teachers of Polish as a foreign language, were asked to decide whether the questions presented in some textbooks are in fact used in everyday conversations. 